J. Product. \& Dev., 17(1):127- 148(2012)

\title{
INFLUENCE OF USING ROCKET SEED (Eruca sative) OIL AND ONION SEED (Allium cepa) OIL ON PRODUCTIVE AND PHYSIOLOGICAL PERFORMANCE OF GROWING RABBITS UNDER HOT CLIMATE CONDITION
}

\section{W. Ezzat ${ }^{*}$ and Saher M. **}

* Poultry Breeding Department, Animal Production Research Institute, Agriculture Center, Egypt

** Poultry Nutrition Department., Animal Production Research Institute, Agriculture Center, Egypt

*Email: dr.waheed_ezzat @yahoo.com

\section{ABSTRACT:}

A completely random experiment was conducted to evaluate rocket and onion seed oils or their mixture under climate summer conditions on growth performance, carcass traits, rectal temperature, respiration rate, immunity (antibody titer against SRBC'S), blood biochemistry, digestibility coefficients, and economical efficiency of growing rabbits, from July to September, 2009.The averages of daily ambient temperature, relative humidity and temperature humidity index (THl) inside the building were $30.27 \pm 0.68^{\circ} \mathrm{C}, 75.95 \pm 2.88 \%$ and 29.36 , respectively.

A total of $96 \mathrm{NZW}$ rabbits, weaned at 6 weeks of age with an average initial body weight, $623.00 \pm 3.09, \mathrm{~g}$ were randomly distributed to four experimental treatments (24 rabbits/ each) then divided into 3 replicates of eight rabbits each. Rabbits were fed the basal diet either unsupplemented (control) or supplemented with $1 \mathrm{~g}$ rocket seed oil/Kg diet, or $1 \mathrm{~g}$ onion seed oil/ Kg diet and their combination throughout the whole experimental period which lasted for 12 weeks. The experimental basal diet was isonitrogenous $(C P=17 \%)$ and isocaloric $(2500 \mathrm{Kcal} / \mathrm{Kg}$ $D E)$.

Results obtained showed that percentages of total unsaturated fatty acids, especially polyunsaturated fatty acid (linoleic) in onion oil were higher than in rocket oil. The percentage of fatty acid Erucic was higher in rocket oil than those in onion oil. Under the high ambient temperatures final body weight and carcass traits of growing rabbits were significantly $(P<0.05)$ increased and feed conversion values were improved with dietary supplementation with either rocket oil or onion 
oils or their mixtures compared with the control group. Dietary either rocket or onion oil and their mixture of growing rabbits ameliorated some of the adverse effects of heat stress on immune response, rectal temperature and respiration rate. Dietary supplementation, also improved $(P \leq 0.05)$ antibody titer against $S R B C$ 'S as compared with the control. Serum total protein and albumin were significantly increased $(P$ $\leq 0.05)$ while, serum total lipids, glucose, AST and ALT concentrations were significantly decreased $(P \leq 0.05)$ due to dietary rocket oil only or with onion oil as compared with the control group. Digestibility coefficients of $C P$ and EE were significantly $(P<0.05)$ affected by dietary addition, being the highest for rocket oil diet, followed by rocket +onion oils diet as compared with the control group. Rocket oil fed group recorded the highest $(P<0.05)$ net return, best economical efficiency and performance index followed by those fed rocket oil plus onion oil and onion oil treatments as compared with the control group.

In conclusion, supplementation of rocket and onion seed oils in growing rabbit diets enhanced growth performance carcass weight and digestibility coefficient of $C P, E E$ and elevated the immunity as well as reduced rectal temperature and respiration rate when growing rabbits were subjected to heat stress.

Keywords: Rocket seed (Eruca sative) oil, onion seed (Allium cepa) oil, growth, thermo-respiratory reaction, immune response, serum constituents, digestibility, rabbits.

\section{INTRODUCTION}

Rabbits are very sensitive to heat stress, as they have difficulties in dissipating body heat when the environmental temperature is high. Exposing rabbits to high ambient temperatures (above $30^{\circ} \mathrm{C}$ ) impaired the growth performance (Fekry, 1989 and Marai et al., 2002), decreased feed consumption, body weight and weight gains (Chiericato et al., I996, Marai et al. 1996 and 2001) whereas, it increased water consumption (Marai et al., 2001 and 2002). In heat-stressed rabbits, both respiration rate and pulse rate are increased ( Marai et al., 2002). Moreover, exposing rabbit to high environmental temperatures resulted in disturbing the normal physiological balance of the animal's body temperature, hormonal and water balances (Habeeb et al., 1997). Under heat stress, plasma T3 and T4 concentrations and the immunity responsiveness were decreased (Mustafa et al., 2008). Siegel (1995) documented that thermal stressors have been shown to reduce concentrations of circulating antibodies and 
suppress cell-mediated immunity resulting in reducing the fitness or survival leading to increasing the mortality.

Rocket oil and onion seed oil (medicinal plant oils) are sources of essential fatty acids and facilitate supply and absorption of the fat soluble vitamins (Clarke et al., 1977). Adding rocket oil and onion seed oil in rabbits diet were found to be effective in alleviating the heat load of rabbits, and they are rich in beneficial factors include special fatty acids (FAs) composition such as high content of oleic acid, monounsaturated FA (MUFA) and polyunsaturated FA (PUFA) or n-3FA, tocopherols, carotenoids and antioxidative phenolic compounds.As well as, it contain natural substances that promote health and ameliorate the body condition to counteract the stress of illness (Eisenberg et al., 1993 and Selim et al., 2003). It has been demonstrated that dietary supplementation with polyunsaturated FAs (PUFAs) improve Ca balance and bone $\mathrm{Ca}$ content in animals and humans (Poulson et al., 2007).

On the other hand, a synergistic effect of hytogenic compounds have been reported in studies with essential oils (Mitsch et al., 2004) and a combination of herbal oils might tends to be more effective than a single herb administration.

Therefore, the objective of the present study was to determine the effect of adding $1 \%$ of onion oil or $1 \%$ rocket oil and their combination to commercial rabbit ration on growth performance, carcass characteristics, thermo-respiratory reaction, immune response, serum constituents, nutrients digestibility of growing rabbit under high ambient temperatures, under Egyptian conditions.

\section{MATERIALS AND METHODS}

The present experiment was carried out in Sakha Research Farm, Animal Production Research Institute, Ministry of Agriculture, Egypt, during the period from July to September, 2009 (the hottest mouths in Egypt).

A total of 96 NZW rabbits, weaned at 6 weeks of age with an average initial body weight of $623.00 \pm 3.09$,g were randomly distributed into four experimental treatments ( 24 rabbits/ each) and each treatment was subdivided four 3 replicates of eight rabbits each. The basal experimental diet was formulated to be isonitrogenous $(17 \% \mathrm{CP})$ and isocaloric $(2500 \mathrm{Kcal} \mathrm{DE}$ / $\mathrm{Kg}$ diet), and to satisfy the nutrient requirements of growing rabbits

according to the Agriculture Ministry Decree recommendations (1996). The feed ingredients and chemical composition of the experimental basal diet are 
presented in Table (1). Rabbits were fed the basal diet either unsupplemented (control) or supplemented with $1 \mathrm{~g}$ rocket seed oil/Kg diet, or $1 \%$ onion seed oil and their combination throughout the whole experimental period which lasted for 12 weeks.

Samples of the different oils were taken to determine the fatty acids composition by using the gas-liquid chromatography (Model: variant 3300; column ov. 101; temperatures of the column, injector and detector were 200, 280 and $240{ }^{\circ} \mathrm{C}$, respectively). Fatty acids were identified by composition of retention times with standers and expressed as percentages of fatty acid methyl ester distribution. Percentages of identified fatty acids were determined by using of digital "Ushikata planimeter (Model DIGI PLAN 220P). The analysis of fatty acids was performed in the Laboratory of Department of Natural Products Chemistry, National Research Center, Dokki, Cairo, Egypt.

Rabbits were housed individually in stainless steel individual cages $(35 \times 35 \times 60 \mathrm{~cm})$ provided with feeders and automatic nipple drinkers. The building used for carrying the experiments was open-air, naturally ventilated and provided with sided electric fans. All rabbits were kept under the same managerial, hygienic and environmental conditions. Diets were offered to rabbits ad libitum and fresh water was available all the time .The averages of ambient temperature, relative humidity and temperature humidity index (THI) during the whole experimental period inside the building were $30.27 \pm 0.68^{\circ} \mathrm{C}$, $75.95 \pm 2.88 \%$ and 29.36 respectively, indicating severe heat stress, according to Marai et al. (2002) who reported that there is severe heat stress when TH1 is higher than 28.9. The THI was calculated according to Marai et al. (2001): $\mathrm{THI}=\mathrm{db}^{0} \mathrm{C}-\left\{(0.31-0.31 \mathrm{RH})\left(\mathrm{db}^{0} \mathrm{C}-14.4\right)\right\}$, where $\mathrm{db}^{0} \mathrm{C}=$ bulb temperature in Celsius and $\mathrm{RH}=\mathrm{RH} \% / 100$. All the experimental rabbits were healthy and clinically free from internal and external parasites.

The rabbits were individually weighed at the beginning of the experiment and then at weekly intervals. Weighing was carried out before offering the morning meal (once a week) at $8.00 \mathrm{~h}$ and the live body gain weight was calculated weekly. Feed consumption and feed conversion values were recorded. 
Table 1. Feed ingredients and chemical composition of the experimental basal diet.

\begin{tabular}{l|c|l|l}
\hline Ingredients & $\mathbf{\%}$ & Calculated analysis $^{\mathbf{2}}(\mathbf{D M}, \mathbf{\%})$ & $\mathbf{\%}$ \\
\hline Clover hay(12\%CP) & 22.50 & Crude protein (CP) & 17.00 \\
Barley grain & 27.25 & Ether extract (EE) & 2.99 \\
Wheat bran & 28.90 & Digestible energy (Kcal/Kg) & 2500 \\
Soybean meal (44\%CP) & 15 & Crude fiber (CF) & 12.00 \\
Molasses & 3.0 & Calcium & 1.09 \\
Dicalcium phosphate & 1.70 & Total phosphorus & 0.8 \\
Limestone & 0.70 & Methionine & 0.41 \\
DL-Methionine & 0.15 & Lysine & 0.72 \\
Vit. and Min. Premix & 0.30 & Cost (LE) / 100 Kg & 180 \\
$\underline{\text { Salt (NaCl) }}$ & $\underline{0.50}$ & & \\
Total & $\mathbf{1 0 0}$ & & \\
\hline
\end{tabular}

(1 ) Each 3 kg vitamin and mineral premix provides: Vit. A $12000000 \mathrm{IU}$, Vit. $\mathrm{D}_{3} 750000 \mathrm{IU}$, Vit. E $10000 \mathrm{mg}$, Vit. K $2000 \mathrm{mg}$, Biotine $50 \mathrm{mg}$, Folic acid $1000 \mathrm{mg}$, Choline choloride $500 \mathrm{mg}$, Selenium $100 \mathrm{mg}$, Manganese $25 \mathrm{~g}$, Zinc $50 \mathrm{mg}$, Fe $60 \mathrm{mg}$, Cu $2.5 \mathrm{mg}$, Co $6 \mathrm{mg}$, Iodine $1 \mathrm{~g}$ and carrier $\mathrm{CaCo}^{3}$ to $3000 \mathrm{gm}$.

(2) According to Feed Composition Tables for Animal Poultry Feedstuffs Used in Egypt (2001).

(3) Calculated according to De Blas and Mateos (1998).

At the end of the experimental period, four rabbits from each treatment were randomly chosen, individually weighed and slaughtered. After complete bleeding, pelt and viscera were removed and then carcass and giblets (liver, heart, and kidneys) were weighed. Dressing percentage included relative weights of carcass, giblets and head were estimated according to Steven et al., (1981). Meat chemical analyses including crude protein $(\mathrm{CP})$, ether extract $(\mathrm{EE})$, and ash were determined according to AOAC (2000).

Respiration rate and rectal temperature were recorded once a week at 9.00- $11.00 \mathrm{~h}$ for each animal. The respiration rate was recorded by counting the flank movements per minute by using a hand counter. The rectal temperature was measured by using a clinical thermometer inserted into the rectum for two minutes at depth of $4 \mathrm{~cm}$.

Blood samples were collected at slaughter from each rabbit to determine blood components. Serum was separated by centrifugation at $5900 \mathrm{~g}$ for $10 \mathrm{~min}$ and frozen at $-20{ }^{\circ} \mathrm{C}$. until analysis. Blood serum total proteins (TP), albumin (ALB), total lipids (TL), total cholesterol (TCH), glucose (GLG), activity of serum aspartate aminotransferase (AST) and alanine aminotransferase (ALT) were calorimetrically determined using commercial kits purchased from BioDiagnostic, Egypt, following the same steps as described by the manufactures. 
However, globulin (GLB) was calculated by the difference between total proteins and albumin. At 12 weeks of age, 4 rabbits from each treatment were immunized by intravenously injection with $0.5 \mathrm{ml}$ of a $40 \%$ suspension of sheep red blood cells (SRBC'S) in sterile saline. Seven days following antigen challenge, blood samples were collected. Approximately, $2.0 \mathrm{ml}$ of blood was drawn from the right biceps femoris muscle of each rabbit. It was allowed to clot to provide serum for antibody titer. Humoral immune response to SRBC'S was measured using microhaemagglutination assay by the method described by Wegmann and Smithies (1966).

At the last week of the experiment, digestibility trial was conducted using four rabbits from each treatment group, housed individually in metabolism cages that allow feces and urine separation. The preliminary period continued for 7 days and the collection period extended for 5 days. Feed and feces were daily recorded quantitatively and chemically analysis according to AOAC (2000).

The economical efficiency (EEf) of the experimental diets was estimated depending on feeding cost and price of meat. Performance index (PI) was calculated according to North (1981) as follows:

$\mathrm{PI}=[$ Live body weight $(\mathrm{Kg}) /$ Feed conversion ratio $] \times 100$.

The data were subjected to one- way statistical analysis applying SAS program (SAS, 2003) using the General Liner Model Program (GLMP). Significant differences among treatment means were separated by Duncan's new multiple-range test (Duncan, 1955).

\section{RESULTS AND DISCUSSION}

\section{Fatty acids composition of rocket and onion oils:}

Results presented in Table (2) showed that the percentages of TUSFA, especially PUSFAs (linoleic) in onion oil were higher than that in rocket oil. The biome chemical functions of PUSFAs are currently under extensive research including their influence/impact on cellular signaling and membrane structure, gene expression and prostaglandin biosynthesis and nervous, endocrine and immune system mediations.

However, the percentage of FAs with C22:1 (Erucic) was higher in rocket oil than in onion oil. These results may indicate that either onion oil or rocket oil are good sources for the essential fatty acids in rabbit diets. Also, the experimental diets containing onion and rocket oils gave the satisfied contents of MUSFAs and PUSFAs. 
Table 2. Fatty acids composition of rocket and onion oils

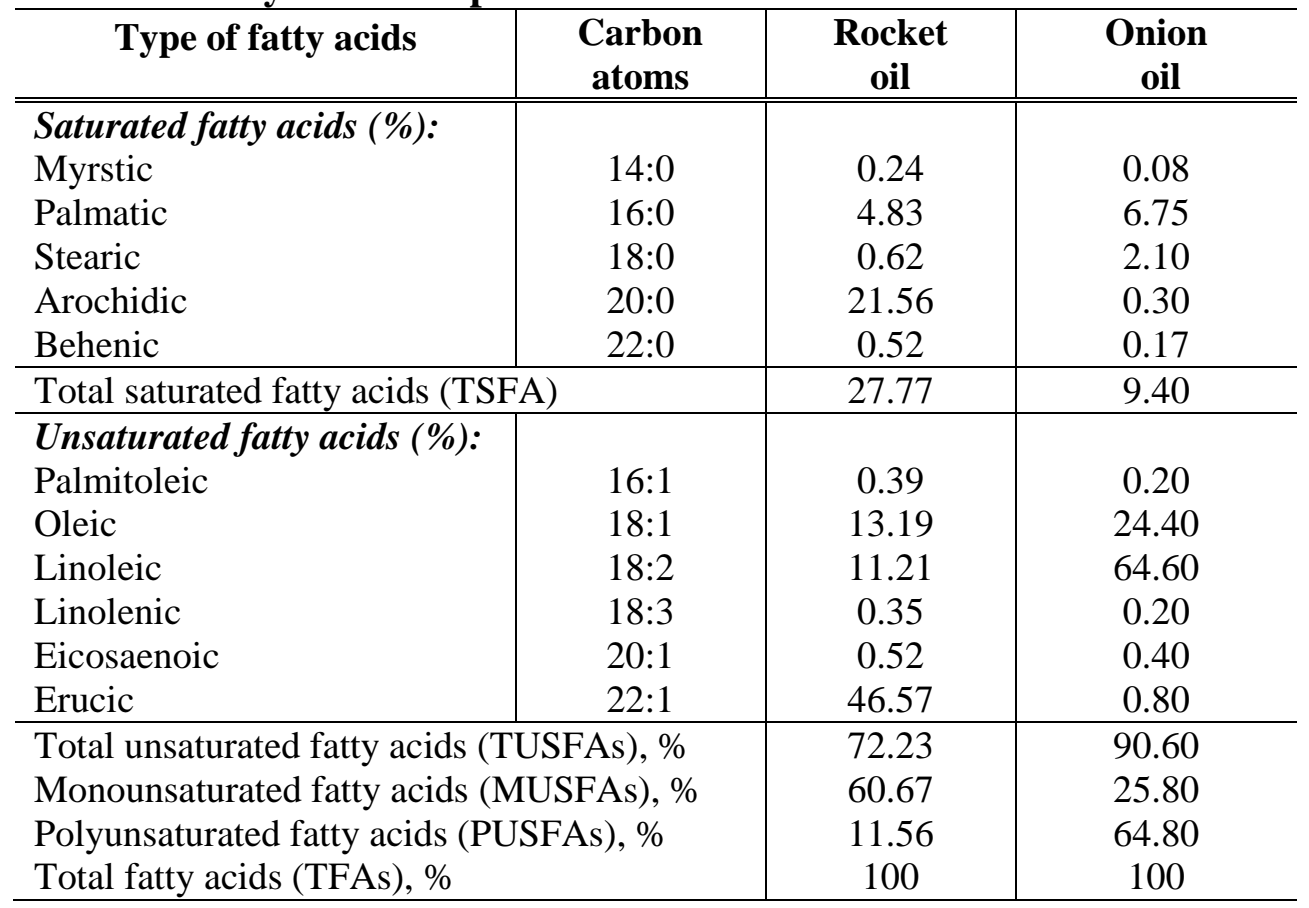

\section{Growth performance:}

Results in Table (3) showed the effect of dietary supplementation of either rocket oil or onion oil and their mixture during summer months on growth performance of growing rabbits. Results indicated that dietary supplementation with either rocket oil or onion oil and their mixture had a positive effect on growth performance of growing rabbits during the period of high ambient temperatures. Under the high ambient temperatures final body weight, daily gain and total gain of growing rabbits were significantly $(\mathrm{P}<0.05$ and $\mathrm{P}<0.01$ ) increased and feed conversion values were improved with dietary supplementation with either rocket oil or onion oil and their mixture compared with those of the control group from 6-18 weeks of age. However, feed intake was not significantly influence by experimental dietary supplementations during the experimental periods. It is noticed that the best values of final body weight, daily gain, total gain and feed conversion of growing rabbits were recorded with dietary supplementation with rocket oil compared with the other group treatments. These improving in growth performance of growing rabbits may be attributed to the properties of these materials that act as antibacterial, antiprotozoal, antifungal and as antioxidant. These results are in agreement 
Table 3. Effect of dietary rocket oil or onion oil and their mixture on growth performance of growing rabbits

\begin{tabular}{lccccc}
\hline Items & Control & Rocket oil & Onion oil & $\begin{array}{c}\text { Rocket oil+ } \\
\text { onion oil }\end{array}$ & Sig. \\
\hline Initial weight, g & 622.29 & 625.83 & 620.00 & 625.63 & NS \\
& \pm 6.33 & \pm 6.38 & \pm 5.70 & \pm 6.28 & \\
Final weight, g & 2161.82 & 2325.91 & 2273.64 & 2294.09 & $*$ \\
& $\pm 33.25^{\mathrm{b}}$ & $\pm 35.78^{\mathrm{a}}$ & $\pm 34.11^{\mathrm{a}}$ & $\pm 37.06^{\mathrm{a}}$ & \\
Daily gain, g & 17.12 & 18.89 & 18.38 & 18.57 & $* *$ \\
& $\pm 0.30^{\mathrm{b}}$ & $\pm 0.34^{\mathrm{a}}$ & $\pm 0.32^{\mathrm{a}}$ & $\pm 0.35^{\mathrm{a}}$ & \\
Total gain, g & 1541.14 & 1700.00 & 1654.55 & 1671.14 & $* *$ \\
& $\pm 27.14^{\mathrm{b}}$ & $\pm 30.85^{\mathrm{a}}$ & $\pm 28.81^{\mathrm{a}}$ & $\pm 31.08^{\mathrm{a}}$ & \\
Daily feed intake, g & 85.48 & $86.82^{2}$ & 86.29 & 86.19 & NS \\
& \pm 1.04 & \pm 0.91 & \pm 1.02 & \pm 1.04 & \\
Feed conversion & 5.03 & 4.63 & 4.72 & 4.68 & $*$ \\
& $\pm 0.11^{\mathrm{b}}$ & $\pm 0.09^{\mathrm{a}}$ & $\pm 0.09^{\mathrm{a}}$ & $\pm 0.11^{\mathrm{a}}$ & \\
Viability \%(6 to18 wks) & 83.33 & 87.50 & 95.83 & 91.67 & \\
\hline
\end{tabular}

Means having different letters within the same row are significantly $(\mathrm{P} \leq 0.05)$ different.

NS $=$ Not significant. $\quad *=\mathrm{P} \leq 0.05 \quad * *=\mathrm{P} \leq 0.01$

with those reported by El-Tohamy and El-Kady (2007), who found that live body weight and daily weight gain of rabbits were significantly increased in those, fed diet containing 50\% rocket seed meal of dietary CP supplied by soybean meal in the control diet. EL-Nattat and EL-Kady (2007). They indicated that $9 \%$ rocket seed meal in the diet gave the best final body weight and feed conversion ratio compared to control. These improvements may be attributed to the properties of this material that act not only as antibacterial, antiprotozoal and antifungal but also as antioxidant (Leung and Foster, 1996). Also, Zeweil et al. (2009) found that feeding rabbits on the diet contained $10.5 \%$ rocket seed meal $(\mathrm{RSM})$ resulted in significant $(\mathrm{P}<0.01)$ improvement in total weight gain by $15.1 \%$ as compared to the control (1042 vs. $905 \mathrm{~g})$, Moreover, addition of water-cress (rocket) up to $3 \%$ in rabbit diets significantly $(\mathrm{P}<0.01)$ improved body weight gain (Ahmed et al., 2005). This may be due to that rocket seeds or meal contains some medicinal substances, considered as a good source of $\beta$-carotene and contains a number of health promoting agents including carotenoids, vitamin C, fibers, glucoerucin and flavonoids (Barillari et al., 2005). The major constituent of rocket seed volatile oil is isothiocyanates, which has antioxidant, antimicrobial and anticarcinogenic activities (Badee et al., 2003; Barillari et al., 2005 and Haristory et al., 2005). In general, rocket (Eruca sativa) is one of the medicinal plants known as an aphrodisiac (Zohara et al., 1998). Moreover, El Hindawy et al.(2003) found a significant $(\mathrm{P} \leq 0.05)$ improvement in growth performance parameters of rabbits 
fed onion seed. Also, Abou El-Wafa et al. (2002) reported that live body weight; daily weight gain and feed conversion values were significantly improved by adding to onion rabbits diet.

\section{Carcass traits and chemical composition of meat:}

Results in Table (4) showed that hot carcass weight and dressing were significantly $(\mathrm{P} \leq 0.05)$ higher for growing rabbits fed diets supplemented with rocket oil and rocket oil plus onion oil as compared with those fed the control diet. Conversely, dietary supplementation had no significant effect on percentages of liver, kidneys, heart and total non-carcass fat. These results are in corresponding with the previous reports of El Hindawy et al. (2003) who found that the dressing percentage of warm carcass (hind limb, trunk, liver and heart) were significantly $(\mathrm{P} \leq 0.05)$ improved for rabbits fed 4, 8, 12 and $16 \%$ onion seed. Also, Abou El-Wafa et al. (2002) reported that significant effect was observed on carcass characters due to onion supplementation.

As shown in Table (4) dietary onion oil and onion oil plus rocket oil supplementation increased $\mathrm{CP}(\mathrm{P} \leq 0.05)$ and decreased $\mathrm{EE}(\mathrm{P} \leq 0.05)$ contents of meat of growing rabbits as compared with those fed the control diet. Conversely, dietary supplementation had no significant effect on DM and ash of meat of growing rabbits. These responses, were similar to those observated of Shehata et al (2010) who found that $\mathrm{CP}$ and $\mathrm{EE}$ contents of rabbits meat were significantly $(\mathrm{P}<0.01)$ higher for growing rabbits fed the diet supplemented with $1.0 \mathrm{~g}$ onion seed oil $/ \mathrm{Kg}$ diet as compared to those fed the control diet.

\section{Some physiological parameters:}

Results in Figures (1 and 2) showed that rectal temperature and respiration rate were significantly $(\mathrm{P} \leq 0.05)$ decreased for growing rabbits fed diets supplemented rocket oil and rocket oil plus onion oil as compared with those fed the control diet. Interestingly, dietary supplementation of growing rabbit diets ameliorated some of the adverse effects of heat stress on rectal temperature and respiration rate. In Egypt, the climate is characterized by a long hot period (from May to October) and short mild one (from December to March). In hot period, rabbits have difficulty in eliminating body heat due to their unfunctional sweat glands (Marai et al., 1996). Different physical and physiological methods have been used to alleviate the heat load in heat stressed animals. The physical methods used are such as sheltering, air conditioning, zone air cooling, drinking cool water, using wet or iced sacks in the cages, spray or sprinkling the roofs and floor with tap water and shearing (Habeeb et al., 1997). 
Table 4. Effect of dietary rocket oil or onion oil and their mixture on carcass traits and chemical composition of meat of growing rabbits at 18 weeks of age.

\begin{tabular}{|c|c|c|c|c|c|}
\hline Items & Control & Rocket oil & Onion oil & $\begin{array}{c}\text { Rocket oil+ } \\
\text { onion oil }\end{array}$ & Sig. \\
\hline Hot carcass weight $(\%)$ & $\begin{array}{c}51.80 \\
\pm 1.03^{\mathrm{b}}\end{array}$ & $\begin{array}{c}55.57 \\
\pm 0.63^{\mathrm{a}}\end{array}$ & $\begin{array}{c}53.84 \\
\pm 0.94^{\mathrm{ab}}\end{array}$ & $\begin{array}{l}55.42 \\
\pm 0.61^{\mathrm{a}}\end{array}$ & * \\
\hline Dressing (\%) & $\begin{array}{c}56.27 \\
\pm 1.00^{\mathrm{b}}\end{array}$ & $\begin{array}{r}59.90 \\
\pm 0.56^{\mathrm{a}}\end{array}$ & $\begin{array}{c}58.20 \\
\pm 1.01^{\mathrm{ab}}\end{array}$ & $\begin{array}{l}59.66 \\
\pm 0.79^{\mathrm{a}}\end{array}$ & * \\
\hline Liver (\%) & $\begin{array}{c}3.40 \\
\pm 0.13\end{array}$ & $\begin{array}{c}3.20 \\
\pm 0.10\end{array}$ & $\begin{array}{c}3.25 \\
\pm 0.15\end{array}$ & $\begin{array}{c}3.11 \\
\pm 0.17\end{array}$ & NS \\
\hline Kidney (\%) & $\begin{array}{c}0.72 \\
\pm 0.03\end{array}$ & $\begin{array}{c}0.75 \\
\pm 0.06\end{array}$ & $\begin{array}{c}0.75 \\
\pm 0.04\end{array}$ & $\begin{array}{c}0.76 \\
\pm 0.05\end{array}$ & NS \\
\hline Heart $(\%)$ & $\begin{array}{c}0.35 \\
\pm 0.04\end{array}$ & $\begin{array}{c}0.38 \\
\pm 0.02\end{array}$ & $\begin{array}{c}0.36 \\
\pm 0.03\end{array}$ & $\begin{array}{c}0.37 \\
\pm 0.03\end{array}$ & NS \\
\hline Giblets (\%) & $\begin{array}{c}4.47 \\
\pm 0.14\end{array}$ & $\begin{array}{c}4.33 \\
\pm 0.07\end{array}$ & $\begin{array}{c}4.36 \\
\pm 0.16\end{array}$ & $\begin{array}{c}4.24 \\
\pm 0.19\end{array}$ & NS \\
\hline Total non-carcass fat (\%) & $\begin{array}{c}1.73 \\
\pm 0.18 \\
\end{array}$ & $\begin{array}{c}1.92 \\
\pm 0.14 \\
\end{array}$ & $\begin{array}{c}1.81 \\
\pm 0.10\end{array}$ & $\begin{array}{r}1.89 \\
\pm 0.12 \\
\end{array}$ & NS \\
\hline \multicolumn{6}{|c|}{ Chemical composition of meat (\% DM basis): } \\
\hline DM & $\begin{array}{l}30.64 \\
\pm 1.41\end{array}$ & $\begin{array}{l}31.17 \\
\pm 1.86\end{array}$ & $\begin{array}{l}32.29 \\
\pm 1.89\end{array}$ & $\begin{array}{l}31.99 \\
\pm 1.48\end{array}$ & NS \\
\hline CP & $\begin{array}{r}62.65 \\
\pm 0.79^{c}\end{array}$ & $\begin{array}{c}64.13 \\
\pm 0.84^{\mathrm{bc}}\end{array}$ & $\begin{array}{c}66.73 \\
\pm 0.80^{\mathrm{a}}\end{array}$ & $\begin{array}{c}66.28 \\
\pm 0.77^{\mathrm{ab}}\end{array}$ & $*$ \\
\hline $\mathbf{E E}$ & $\begin{array}{l}24.92 \\
\pm 0.15^{\mathrm{a}}\end{array}$ & $\begin{array}{l}24.04 \\
\pm 0.21^{\mathrm{b}}\end{array}$ & $\begin{array}{c}23.92 \\
\pm 0.27^{\mathrm{b}}\end{array}$ & $\begin{array}{c}23.99 \\
\pm 0.18^{\mathrm{b}}\end{array}$ & $*$ \\
\hline Ash & $\begin{array}{c}4.18 \\
\pm 0.12\end{array}$ & $\begin{array}{c}4.16 \\
\pm 0.19\end{array}$ & $\begin{array}{c}4.27 \\
\pm 0.14\end{array}$ & $\begin{array}{c}4.24 \\
\pm 0.16\end{array}$ & NS \\
\hline
\end{tabular}

Means having different letters within the same row are significantly $(\mathrm{P} \leq 0.05)$ different.

$\mathrm{NS}=$ Not significant. $\quad *=\mathrm{P} \leq 0.05 \quad * *=\mathrm{P} \leq 0.01$

However, in all cases rabbits must be kept dry, since wet coats are predisposing causes for pneumonia and respiratory troubles (Marai et al., 1996) which have led to the investigation of a number of dietary agents which might alleviate the adverse effects of temperature. It is well known that body temperature and respiration rate are increased following exposure to high $\left(>30^{\circ} \mathrm{C}\right)$ environmental temperatures (Habeeb et al., 1997; Marai et al 2001, 2002). In this respect, due to its ability in reducing body temperature and consequently respiration rate, rocket oil or onion oil and their mixture might be supplemented to the growing rabbit diets during hypothermic stress in order to alleviate some of the adverse effects of heat stress.

From another point of view, the increase in body temperature due to the exposure to ambient temperatures above the thermal comfort zone has a negative 

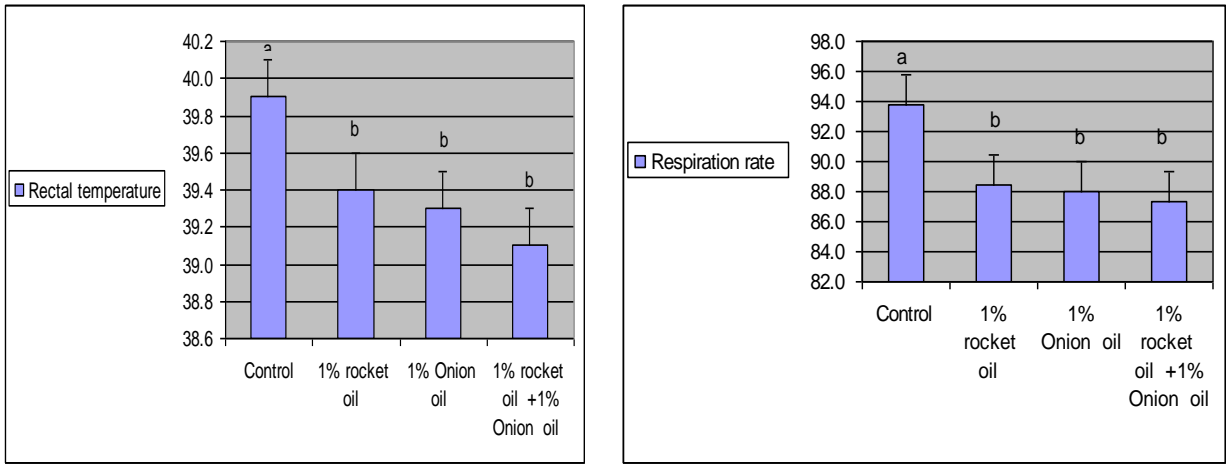

Figures (1 and 2): Effect of dietary rocket oil or onion oil and their mixture on rectal temperature and respiratory rate of growing rabbits.

impact on animal performance via decreasing feed intake, body weight gain and the resistance to disease and increasing the feed conversion ratio (Habeeb et al., 1997and Marai et al. 2001). The decrease in feed consumption is due to impairment of appetite as a result to stimulation of the peripheral thermal receptors by the environmental temperature to transmit suppressive nerve impulses to the appetite center in the hypothalamus that causes that phenomenon (Marai et al,. 2002). Since rocket oil or onion oil and their mixture had a significant effect in reducing body temperature which consequently participated in enhancing feed intake and body weights as well as carcass yield (Tables $3 \&$ 4). It could be assumed that dietary rocket oil or onion oil and their mixture supplemention might help to overcome the negative effects of heat stress on growth performance and carcass yield.

\section{Immunity:}

The influences of either dietary rocket oil or onion oil and their mixture during summer months on antibody titer against SRBC'S are graphically presented in Figure 3. It is interesting to note that either dietary rocket oil or onion oil and their mixture supplementation improved antibody titer against SRBC'S as compared with the control. These results are in accordance with some published data Ewa Ostrowska (2004) showed that onion have functional properties with the ability to modify lipid metabolism and stimulate the immune system.

\section{Blood serum metabolites:}

Protein fractions of growing rabbits at the end of experimental period (18 weeks of age) as affected by either dietary rocket oil or onion oil and their 


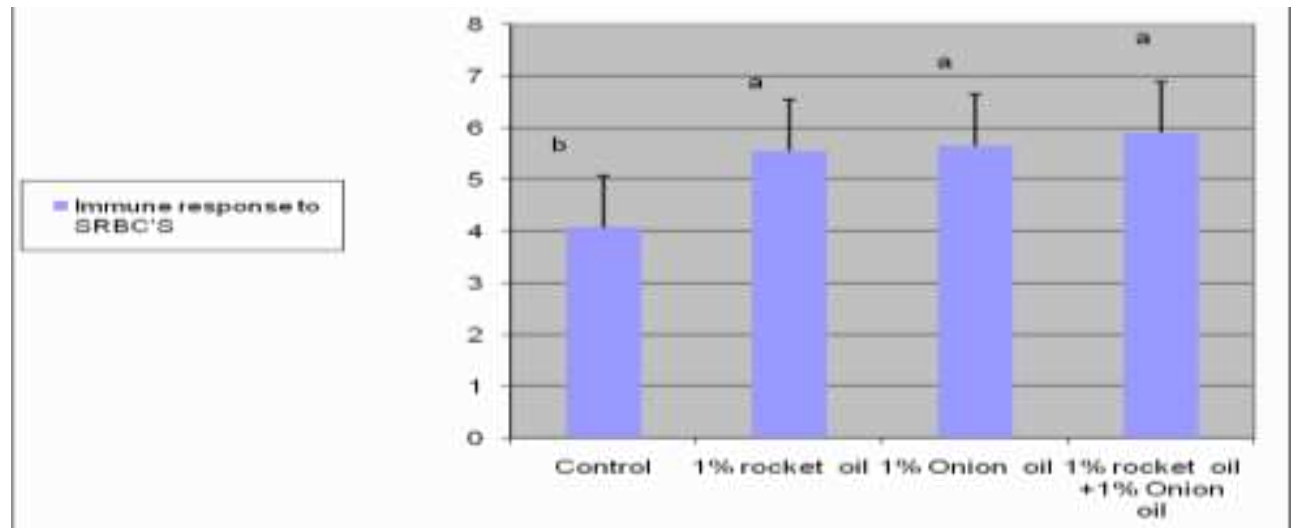

Figure 3. Effect of dietary rocket oil or onion oil and their mixture on immunity of growing rabbits.

mixture under hot summer conditions are presented in Table 5. Since albumin and globulin are two key components of serum proteins, because albumin is synthesized in the liver, one element is used to monitor the liver function (Friedeman et al. 1980). Growing rabbits received dietary rocket oil recorded the highest $(\mathrm{P} \leq 0.05)$ values of serum total protein and albumin followed those fed dietary by rocket plus onion oils compared with values of rabbits fed the control diet. These results are in agreement with those of Hussein et al. (2007) who found that garlic and onion oils improved serum total protein and albumin. In the current study, the significant increase in serum total protein and albumin observed in growing rabbits fed dietary rocket oil and onion oil indicates the ability of these oils to stimulate the regeneration of hepatic tissue which increase protein synthesis in liver and improved the functional status of the liver cells. Also, Zeweil et al. (2009) found that serum total protein and globulin of rabbits fed $10.5 \%$ rocket seed meal-diet were significantly higher than those fed the control diet. Additionally, in the current study (Table 5), growing rabbits received dietary rocket oil recorded the lowest $(\mathrm{P} \leq 0.05)$ values of total lipids and cholesterol followed by those fed dietary rocket oil plus onion oil. However, the control group recorded the highest values. These results are in agreement with those of Mukherjee et al.(2004) and Yazdanparast et al. (2008) who reported that intragastric administration of Nasturtium officinale (Rocket) (500 $\mathrm{mg} / \mathrm{Kg}$ body weight per day) to groups of hypercholesterolaemic rats for 30 days lowered their blood total lipids, total cholesterol and triglycerides. The mechanism of action was suggested by Sodimu et al. (1984) who indicated that garlic oil prevented the increase of cholesterol, triglycerides and total lipids by inactivation of thiol group enzymes as $\mathrm{HMG}-\mathrm{CoA}$ reductase and Co ASH. In the 
Table 5. Effect of dietary rocket oil or onion oil and their mixture on blood serum constituents of growing rabbits at 18 weeks of age.

\begin{tabular}{lccccc}
\hline Items & Control & Rocket oil & Onion oil & $\begin{array}{c}\text { Rocket oil+ } \\
\text { onion oil }\end{array}$ & Sig. \\
\hline Total Protein (g/dl) & 5.30 & 6.01 & 5.90 & 5.95 & $*$ \\
& $\pm 0.16^{\mathrm{b}}$ & $\pm 0.14^{\mathrm{a}}$ & $\pm 0.10^{\mathrm{a}}$ & $\pm 0.14^{\mathrm{a}}$ & \\
Albumen (g/dl) & 3.01 & 3.54 & 3.50 & 3.51 & $*$ \\
& $\pm 0.11^{\mathrm{b}}$ & $\pm 0.14^{\mathrm{a}}$ & $\pm 0.09^{\mathrm{a}}$ & $\pm 0.08^{\mathrm{a}}$ & \\
Globulin (g/dl) & 2.29 & 2.92 & 2.85 & 2.89 & $\mathrm{NS}$ \\
& \pm 0.07 & \pm 0.03 & \pm 0.02 & \pm 0.11 & \\
Total lipids (mg/dl) & 401.34 & 292.35 & 307.36 & 296.01 & $*$ \\
& $\pm 27.83^{\mathrm{a}}$ & $\pm 25.80^{\mathrm{b}}$ & $\pm 26.61^{\mathrm{b}}$ & $\pm 27.92^{\mathrm{b}}$ & \\
Cholesterol (mg/dl) & 88.97 & 87.40 & 88.06 & 87.01 & $\mathrm{NS}$ \\
& \pm 2.00 & \pm 1.79 & \pm 2.39 & \pm 2.62 & \\
Glucose(mg/dl) & 142.14 & 122.11 & 113.35 & 116.76 & $*$ \\
& $\pm 5.81^{\mathrm{a}}$ & $\pm 5.75^{\mathrm{b}}$ & $\pm 4.50^{\mathrm{b}}$ & $\pm 5.11^{\mathrm{b}}$ & \\
AST (IU/L) & 32.89 & 27.53 & 29.16 & 27.81 & $*$ \\
& $\pm 1.35^{\mathrm{a}}$ & $\pm 1.20^{\mathrm{b}}$ & $\pm 1.21^{\mathrm{an}}$ & $\pm 1.17^{\mathrm{b}}$ & \\
ALT (IU/L) & 14.04 & 10.41 & 10.79 & 10.27 & $*$ \\
& $\pm 0.99^{\mathrm{a}}$ & $\pm 0.96^{\mathrm{b}}$ & $\pm 0.92^{\mathrm{b}}$ & $\pm 0.94^{\mathrm{b}}$ & \\
\hline
\end{tabular}

Means having different letters within the same row are significantly $(\mathrm{P} \leq 0.05)$ different. NS $=$ Not significant. $\quad *=\mathrm{P} \leq 0.05 \quad * *=\mathrm{P} \leq 0.01$

diabetic rats, Mi-Ae et al., (2009) reported that onion decreased the total serum lipids, triglycerides. Serum lipids lowering effect of onion can be one of the mechanisms of anti-diabetic effects and contribute to the prevention of diabetic nephropathy. Hyperlipidemia is a risk factor for declining kidney function in patients with diabetic nephropathy (Bordia et al 1975). It was also reported that patients with low serum cholesterol concentration exhibited a lower degree of kidney lesions than those with high serum cholesterol concentration (Mulec et al., 1990).

Rocket oil or onion oil and their mixture supplementation significantly ( $\mathrm{P}$ $\leq 0.05$ ) decreased serum glucose concentration linearly in a dose-dependent manner (Table 5) compared with the control diet values. Onion and rocket might play an important role to prevent complications of diabetes by maintaining blood glucose. It is well established that under stress conditions, glucose uptake of the cells is suppressed and the level of serum glucose is increased in order to serve adequate amount of glucose to sensitive organs such as heart and brain (Lillehoj et al., 1992). In the current study, the decline in serum glucose concentration may be ascribed to the higher level of growth hormone and insulin in rabbits fed dietary rocket oil or rocket plus onion oils. This assumption comes in harmony 
with that of Galeone et al (2006) who reported that onion is said to contain antioxidants. Onion may have stimulated pancreatic $\beta$-cells which may enhance their production of insulin (Opara, 2004), and, more importantly, the possibility that onion may enhance cellular response to insulin (making target cells more responsive to insulin). Mi-Ae et al.,(2009) reported that blood glucose levels of rats supplemented with onion (powder $7 \% \mathrm{w} / \mathrm{w}$ ) were lower than those of rats fed control diet in the diabetic rats.

In the present study, liver function was improved a liver enzymes (e.g. AST and ALT) were significantly decreased by dietary rocket oil or onion oil and their mixture (Table 5). This assumption comes in harmony with those of Abdo (2003) who reported that including rocket seed meal in broiler diets resulted in significant decrease in serum AST and ALT activities. This decrease may be due to their antioxidant status as reported by Bradley (1992). It is important to mention that, according to to Okerman (1994), the values obtained in current trail are within the normal ranges of these enzymes in rabbits. Marai et al. (2002) reviewed that serum transaminase activities (AST and ALT) are increased during the hot summer in rabbits, Therefore, it could be concluded that dietary rocket oil or onion oil and their mixture supplementation help in keeping serum transaminase enzymes within the normal ranges during heat stress conditions.

\section{Digestibility coefficients and nutritive values:}

Data in Table (6) cleared that only digestibility coefficients of $\mathrm{CP}$ and $\mathrm{EE}$ were significantly $(\mathrm{P}<0.05)$ increased by dietary supplementation, being the highest for rocket oil diet, followed by rocket +onion oils diet. However, digestion of DM, OM, CF and NFE values were not significantly affected by dietary addition.

Also, inclusion of rocket oil and their combination with onion oil in the diets of rabbits significantly $(\mathrm{P}<0.05)$ improved the nutritive value of $\mathrm{DCP}$ compared with the other treatments and control diet. These results are in coincident with those of Soliman et al. (2006), who reported that feeding growing rabbits on rocket seed meal diet had no adverse effect on digestibility coefficients and nutritive values. Also, Bassuny (1999) noticed significant $(\mathrm{P}<0.05)$ increase in $\mathrm{EE}$ and NFE, nutritive values (TDN and DCP) with the increase of DE and CP contents in the diet. Ahmed et al. (2005) showed that addition of water-cress up to $3 \%$ in rabbit diets significantly $(\mathrm{P}<0.01)$ improved apparent digestibility coefficients of most feed nutrients. 
Table 6. Digestion coefficients and nutritive values of experimental diets as affected by dietary supplementation of rocket oil or onion oil and their mixture.

\begin{tabular}{|c|c|c|c|c|c|}
\hline Items & Control & Rocket oil & Onion oil & $\begin{array}{c}\text { Rocket oil+ } \\
\text { onion oil }\end{array}$ & Sig. \\
\hline \multicolumn{6}{|c|}{ Digestion coefficients (\%): } \\
\hline \multirow[t]{2}{*}{$\mathrm{DM}$} & 65.45 & 67.60 & 66.90 & 65.00 & \multirow{2}{*}{ NS } \\
\hline & \pm 2.13 & \pm 2.01 & \pm 2.07 & \pm 2.37 & \\
\hline \multirow[t]{2}{*}{$\mathrm{OM}$} & 65.03 & 67.95 & 67.01 & 66.74 & \multirow{2}{*}{ NS } \\
\hline & \pm 1.56 & \pm 1.44 & \pm 1.35 & \pm 1.45 & \\
\hline \multirow[t]{2}{*}{$\mathrm{Cp}$} & 64.84 & 69.43 & 67.65 & 69.17 & \multirow[t]{2}{*}{$*$} \\
\hline & $\pm 0.81^{\mathrm{b}}$ & $\pm 1.14^{\mathrm{a}}$ & $\pm 0.90^{\mathrm{ab}}$ & $\pm 1.11^{\mathrm{a}}$ & \\
\hline \multirow[t]{2}{*}{$\mathrm{CF}$} & 24.58 & 23.56 & 24.25 & 23.39 & \multirow[t]{2}{*}{ NS } \\
\hline & \pm 1.69 & \pm 1.55 & \pm 1.52 & \pm 1.63 & \\
\hline \multirow[t]{2}{*}{$\mathrm{EE}$} & 70.26 & 77.27 & 74.22 & 75.78 & \multirow[t]{2}{*}{$*$} \\
\hline & $\pm 1.63^{\mathrm{b}}$ & $\pm 1.51^{\mathrm{a}}$ & $\pm 1.47^{\mathrm{ab}}$ & $\pm 1.50^{\mathrm{a}}$ & \\
\hline \multirow[t]{2}{*}{ NFE } & 71.01 & 73.62 & 73.26 & 72.97 & \multirow[t]{2}{*}{ NS } \\
\hline & \pm 1.48 & \pm 1.56 & \pm 1.87 & \pm 1.70 & \\
\hline \multicolumn{6}{|c|}{ Nutritive values (\%): } \\
\hline \multirow[t]{2}{*}{ TDN } & 59.27 & 61.84 & 61.23 & 61.31 & \multirow[t]{2}{*}{$\mathrm{NS}$} \\
\hline & \pm 0.94 & \pm 0.75 & \pm 1.10 & \pm 1.27 & \\
\hline \multirow[t]{2}{*}{ DCP } & 10.85 & 11.62 & 11.32 & 11.58 & \multirow[t]{2}{*}{$*$} \\
\hline & $\pm 0.13^{\mathrm{b}}$ & $\pm 0.19^{\mathrm{a}}$ & $\pm 0.15^{\mathrm{ab}}$ & $\pm 0.19^{\mathrm{a}}$ & \\
\hline DEE & $\begin{array}{c}2625.54 \\
\pm 41.77\end{array}$ & $\begin{array}{c}2739.55 \\
\pm 33.27\end{array}$ & $\begin{array}{c}2712.67 \\
\pm 48.56\end{array}$ & $\begin{array}{c}2716.06 \\
\pm 56.17\end{array}$ & NS \\
\hline
\end{tabular}

Means having different letters within the same row are significantly $(\mathrm{P} \leq 0.05)$ different.

$\mathrm{NS}=$ Not significant. $\quad *=\mathrm{P} \leq 0.05 \quad * *=\mathrm{P} \leq 0.01$.

\section{Economical efficiency:}

Data in Table (7) showed that rocket oil fed group recorded the highest $(\mathrm{P}<0.05)$ net return, best economical efficiency and performance index followed by those fed rocket oil plus onion oil and onion oil treatments as compared with the control . These results are attributed to the high $(\mathrm{P}<0.05)$ total weight gain of this treatment and better $(\mathrm{P}<0.05)$ performance index. The results of economical efficiency support those obtained by Shehata et al (2010) showed that the best economical efficiency value was recorded for rabbits fed diets supplemented with onion seed oil at the level of $1.0 \mathrm{~g} / \mathrm{Kg}$ diet than the other treatment groups.

Conclusively, based on the pervious data, it could be concluded that supplemental dietary rocket and onion oils enhanced growth performance, and carcass weight, stabilized the normal physiological balance, and elevated the immunity (antibody titer against SRBC'S), as well as, reduced rectal temperature, respiration rate and recorded the best economical efficiency and 
Table 7. Effect of dietary of dietary rocket oil or onion oil and their mixture on economical efficiency of growing rabbits at 18 weeks of age.

\begin{tabular}{|c|c|c|c|c|c|}
\hline Items & Control & Rocket oil & Onion oil & $\begin{array}{c}\text { Rocket oil+ } \\
\text { onion oil }\end{array}$ & Sig. \\
\hline Total feed intake $(\mathrm{Kg})$ & $\begin{array}{r}7.69 \\
\pm 0.09\end{array}$ & $\begin{array}{c}7.81 \\
\pm 0.08\end{array}$ & $\begin{array}{c}7.77 \\
\pm 0.09\end{array}$ & $\begin{array}{c}7.76 \\
\pm 0.09\end{array}$ & NS \\
\hline Price of $\mathrm{Kg}$ diet & 1.800 & 1.810 & 1.816 & 1.813 & - \\
\hline Total feed cost /rabbit (LE) & $\begin{array}{l}13.85 \\
\pm 0.17\end{array}$ & $\begin{array}{l}14.14 \\
\pm 0.15\end{array}$ & $\begin{array}{l}14.10 \\
\pm 0.17\end{array}$ & $\begin{array}{l}14.06 \\
\pm 0.17\end{array}$ & NS \\
\hline Total weight gain $(\mathrm{Kg})$ & $\begin{array}{c}1.54 \\
\pm 0.03^{\mathrm{b}}\end{array}$ & $\begin{array}{c}1.70 \\
\pm 0.03^{\mathrm{a}}\end{array}$ & $\begin{array}{c}1.65 \\
\pm 0.03^{\mathrm{a}}\end{array}$ & $\begin{array}{r}1.67 \\
\pm 0.03^{\mathrm{a}}\end{array}$ & $* *$ \\
\hline Price/kg live body weight (LE) & 16.00 & 16.00 & 16.00 & 16.00 & \\
\hline Selling price of Kg gain rabbit & $\begin{array}{l}24.66 \\
\pm 0.43^{\mathrm{b}}\end{array}$ & $\begin{array}{l}27.20 \\
\pm 0.49^{\mathrm{a}}\end{array}$ & $\begin{array}{l}26.47 \\
\pm 0.46^{\mathrm{a}}\end{array}$ & $\begin{array}{l}26.74 \\
\pm 0.50^{\mathrm{a}}\end{array}$ & $* *$ \\
\hline Net return/ rabbit (L.E) & $\begin{array}{c}10.81 \\
\pm 0.49^{\mathrm{b}}\end{array}$ & $\begin{array}{l}13.06 \\
\pm 0.49^{\mathrm{a}}\end{array}$ & $\begin{array}{c}12.37 \\
\pm 0.45^{\mathrm{a}}\end{array}$ & $\begin{array}{l}12.68 \\
\pm 0.54^{\mathrm{a}}\end{array}$ & $*$ \\
\hline Economical efficiency(EEf) ${ }^{x}$ & $\begin{array}{l}78.78 \\
\pm 4.09^{\mathrm{b}}\end{array}$ & $\begin{array}{r}92.64 \\
\pm 3.73^{\mathrm{a}}\end{array}$ & $\begin{array}{c}88.13 \\
\pm 3.46^{\mathrm{ab}}\end{array}$ & $\begin{array}{c}90.84 \\
\pm 4.38^{\mathrm{ab}}\end{array}$ & NS \\
\hline Relative EEf , $\%$ & 100.00 & 118.25 & 112.36 & 115.46 & - \\
\hline Performance index (\%) & $\begin{array}{c}43.78 \\
\pm 1.62^{\mathrm{b}} \\
\end{array}$ & $\begin{array}{r}50.98 \\
\pm 1.69^{\mathrm{a}} \\
\end{array}$ & $\begin{array}{l}48.82 \\
\pm 1.53^{\mathrm{a}} \\
\end{array}$ & $\begin{array}{r}49.97 \\
\pm 1.86^{\mathrm{a}} \\
\end{array}$ & $*$ \\
\hline $\begin{array}{l}\mathrm{a}, \mathrm{b} \text { Means having different } \mathrm{l} \\
\mathrm{NS}=\text { Not significant. } \\
\alpha \text { Economic efficiency= net } \\
\text { total feed cost. } \\
\text { \# Assuming that the relative }\end{array}$ & $\begin{array}{l}*=\mathrm{P} \leq 0.05 \\
\text { turn/total }\end{array}$ & $\begin{array}{r}\text { he same ro } \\
* * \\
\text { ed } \operatorname{cost}^{*} 10 \\
\text { iciency of }\end{array}$ & $\begin{array}{l}\text { are signific } \\
P \leq 0.01 \\
\text { Whereas n } \\
\text { e control d }\end{array}$ & $\begin{array}{l}\text { tly }(\mathrm{P} \leq 0.05) \mathrm{d} \\
\text { revenue }=\text { total } \\
\text { equals } 100 \text {. }\end{array}$ & Eerent. \\
\hline
\end{tabular}

\section{REFERENCES}

Abdo, M.A. Zeinab (2003). Using Egyptian Eruca-Sativa meal in broiler ration with or without microbial phytase. Egypt. J. Nutr. Feeds, 6: 97-114.

Abou El-Wafa, S.; A.A. Sedki and A.M. Ismail (2002). Response of growing rabbits to diets containing black seed, garlic or onion as natural feed additives. Egypt. J. Rabbit Sci.,12 (1): 69-83.

Agriculture Ministry Decree (1996). The Standard Properties For Ingredients. Feed Additives and Feed Manufactured for Animal and Poultry, ElWkaee El- Masria. No, 192 ( 1997) Amirria Press Cairo , Egypt, PP95. 
Ahmed, Soad, A. ; K. M. El-Gendy ; M. A. Sarhan ; M. I. Tawfeek and H. M. El-Kelawy (2005). Response of rabbits to diets containing watercress (Nasturtium officianale) as a nutral feed additives. $3^{\text {rd }}$ InteRr Poult. Conf. , 4-7 Apr., Hurghada, Egypt, 491-505.

Association of Official Analytical Chemists, AOAC, (2000). Official method of analysis 942.05 ( $17^{\text {th }}$ Edition) Volume I., Inc., Maryland, USA.

Badee, Z. M. ; S. A. Hallabo and A. A. Aol (2003). Biological evaluation of Egyptian Eruca sativa seeds and leaves. Egypt. J. Food Sci., 31: 67-78.

Barillari, J. D. ; G. F. Pedulli and L. Valgimigli (2005). Direct antioxidant activity of purified glucoerucin, the dietary secondary metabolite contained in rocket (Eruca sativa mill) seeds and sprouts. J. Agric. Food Che., 6: $2475-2482$.

Bassuny, S. M. (1999). Performance of doe rabbits and their weanlings as affected by heat stress and their alleviation by nutritional means under Egyptain condition. Egypt. J. Rabbit Sci., 9 (1): 73-86.

Bordia, A.; H.C.Bansal; S.K. Arora and S.V. Singh (1975). Effect of essential oils of garlic and onion on alimentary hyperlipidemia. Atherosclerosis, 21:15-19.

Bradley, P.R. (1992). British Herbal Compendium, Vol. 1,. Boumemouth: British Herbal Medicine Association, 395-399.

Chiericato, G. M.; C. Rizzi and V. Rosteliato (1996). Effect of genotype and environmental conditions on the productive and slaughtering performance of growing meat rabbits. Proc. $6^{\text {th }}$ World Rabbit Con., Toulouse, 3: 147-151.

Clarke, H. E. ; M. F. Coats; J. K. Eva; P. P. Scott and R. J. Whrd (1977). Dietary standards for laboratory animals: report of the Laboratory Animals Center Diets Advisory Committee. Lab. Anim, 11: 1-28.

De Blas, J. C. and G. G. Mateos (1998). Feed formulation. In : The Nutrition of the Rabbits (De Blas, J. C. and J. Wiseman, Eds), CABI Publ. Wallingford, UK, PP. 241-254.

Duncan, D. B. (1955). The Multiple Range and Multiple F-Test. Biometrics, 11: $1-42$.

Eisenberg, D. M. ; R. C. Kessler; C. Foster and T. L. Delbanco, (1993). Unconventional medicine in the united states. Preference, cost and patterns of use. N. England J. Med., 328: 246-252.

El-Hindawy, M.M. ; M.H. Yacout; J.J. Hassan and N.A. Ebidalla (2003). Evaluation of onion seeds as unconventional feed stuff for growing rabbits. Egypt. J. Rabbit Sci., 13(2)183-194. 
EL-Nattat, W.S. and R.I. EL-Kady (2007). Effect of different medicinal plant seeds residues on the nutritional and reproductive performance of adult male rabbits. Int. J. Agri. Biol., 9 (3): 479-485.

El-Tohamy, M. M. and R.I. EL-Kady (2007). Partial replacement of soybean meal with some medicinal plant seed meal and their effect on the performance of rabbits. Int. J. Agri. Biol.,9 (2): 215-219.

Ewa Ostrowska; Nicholas K.; Gabler, Sam J. ;Sterling, B. G. Tatha; R. B. Jones; D. R. Eagling; M. Jois and F. R. Dunshea (2004) Consumption of brown onions (Allium cepa var. cavalier and var. destiny) moderately modulates blood lipids, haematological and haemostatic variables in healthy pigs. Br. J. of Nutr., 91: 211-218.

Feed Composition Tables For Animal and Poultry Feedstuffs Used In Egypt (2001). Technical Bulletin, No. 1, Central Lab for Feed and Food, Ministry of Agriculture, Egypt.

Fekry, A.E. (1989). Body composition responses to exposure to direct solar radiation. Proc. $3^{\text {rd }}$ Egyptian-British Conference on Animal, Fish and Poultry Prod, Alexandria University, Alexandria, Egypt, 2:649-656.

Friedeman, R.B.; R.E. Anderson; S.M. Entine and S.B. Hirshberg (1980). Effects of diseases in clinical laboratory tests. Clin. Chem., 26 (Suppl.4), 1D-476D.

Galeone, C; C . Pelucchi; F. Levi; E. Negri; S.Franceschi; R. Talamini; A. Giacosa and C. La Vecchia (2006). Onion and garlic use and human cancer. Am. J. of Clin. Nutr., 84 (5):1027-32

Habeeb, A. A. M.; I. F. M. Marai; A. M. El-Maghawry and A. E. Gad (1997). Growing rabbits as affected by salinity in drinking water under winter and hot summer conditions of Egypt. Egypt. J. Rabbit Sci., 7: 81-94.

Haristory, X. J. ; I. Scholtus and A. Lozniewski (2005). Evaluation of the antimicrobial effects of several isothiocyanates on helicobacterpylori. Plant Med., 71: 326-330.

Hussein, J .S.; F.S. Oraby and N. El-Shafey (2007). Antihepatotoxic effect of garlic and onion oils on ethanol-induced liver injury in rats. Journal of Applied Sciences Research, 3(11): 1527-1533.

Leung, A.Y. and S. Foster (1996). Drugs and Cosmetics, $2^{\text {nd }}$ Encyclopedia of Common Natural Ingredients Used in Food. John Wiley and Sons Inc., New York, USA.

Lillehoj, H. S.; B. Kaspers; M.C. Jenkins and E. P. Lillehoj (1992). Avian interferon and interleukin -2. A review by comparison with mammalian homologues. Poultry Sci.Rev., 4: 67-85. 
Marai, I. F. M.; M. S. Ayyat and U. M. Abd El-Monem (2001). Growth performance and reproductive traits at first parity of New Zealand White female rabbits as affected by heat stress and its alleviation, under Egyptian conditions. Trop. Anim. Healt. Prod., 33: 1-12.

Marai, I. F. M.; M. S. Ayyat; H. A. Gabr and U. M. Abd El-Monem (1996). Effect of summer heat stress and its amelioration on production performance of New Zealand White adult female and male rabbits, under Egyptian conditions. Proc. $6^{\text {th }}$ World Rabbit Cong., Toulouse, France, 2: 197-208.

Marai, I. F. M.; A. A. M. Habeeb and A. E. Gad (2002). Rabbits' productive, reproductive and physiological performance traits as affected by heat stress: a review. Livest. Prod. Sci., 78: 71-90.

Mi-Ae Bang; A. K. Hyeon and Y.Ja. Cho (2009). Alterations in the blood glucose, serum lipids and renal oxidative stress in diabetic rats by supplementation of onion (Allium cepa. Linn). Nutr. Res. Pract., 3:242246.

Mitsch, P. ; C. Gabler ; P. Losa, and I. Zimpernik (2004). The effect of two different blends of essential oil components on the proliferation of clostridium perfringens in the intestines of broiler chicken. Poultry Sci., 83: 669-675.

Mukherjee, M.; A.S. Das; S. Mitra and C. Mitra (2004). Prevention of Bone loss by oil extract of garlic (Allium sativum Linn.)in an ovariectomized rat model of osteoporosis. Phytother. Res., 18: 389-394.

Mulec, H.; S.A. Johnson and S. Bjorck (1990). Relationship between serum cholesterol and diabetic nephropathy. Lancet, 335:1537-1538.

Mustafa, A.; S.D. Holladay ;M. Goff ; S.G. Witonsky ;R. Kerr ; C.M. Reilly ; D.P. Sponenberg and R.M. Jr. Gogal (2008). An enhanced postnatal autoimmune profile in 24 week-old c57b1/6 mice developmentally exposed to tcdd. Toxicol. Appl. Pharmacol., 232(1):51-59.

North, M.O. (1981). Commercial Chicken. Production Annual. $2^{\text {nd }}$ Edition, Av., Publishing Company I.nc., West Post, Connecticut, USA.

Okerman, L .(1994), Laboratory investigations as a diagnostic aid.In: Okerman L. Diseases of Domestic Rabbits. 2nd Edition. Blackwell Scientific Publications., 42 -47.

Opara, E.I. (2004). The efficacy and safety of Chinese herbal medicines. $B r . J$. Nutr., 91:171-173.

Poulson, R. C. ; P. J. Moughan and M. C. Kruger(2007). Long-chain polyunsaturated fatty acids and the regulation of bone metabolism. Exp. Biol. Med., 232 (10):1275-1288. 
SAS (2003). SAS User's Guide: Statistics. Version 8.2, SAS Institute Inc., Cary, NC.

Selim, A. D. ; Z. M. Soliman and A. M. A. Abdel-Khalek (2003). Effect of the introduction between drinking water temperature and some dietary feed additives on performance of heat stressed rabbits. Egypt. J. Nutr. Feeds., 231-244.

Shehata, M. A; A. Bealish; Saher, M. Hamid and A. S. Shehata (2010). Influence of using onion seed (allium cepa) oil and calcium sources in ration on growth performance and immunology of growing rabbits. The $6^{\text {th }}$ Inter. Con .on Rabbit Prod. in Hot Clim., Assuit, Egypt., pp. 263-281.

Siegel, H.S. (1995) Stress, strains and resistance. Br. Poult. Sci., 36: 3-22.

Sodimu, O.; P.K. Joseph and K.T. Augusti (1984). Certain biochemical effects of garlic oil on rats maintained on high fat- high cholesterol diet. Experiential, 40: 78-80.

Soliman, M. Z. A. ; Fatma G. Ahmed ; M. A. F. El-Manylawi and Fatma, T. F. Abd El-Ghany (2006). Evaluation of using some Agro-industrial byproducts in growing rabbit nutrition., Egypt. J. Rabbit Sci., 16: 297-323.

Steven, W.D.; W.D. Hohenboken; P.R. Cheeke; N.M. Patton and W.H. Kennick (1981). Carcass and meat characteristics of Flemish Giant and New Zealand White purebred and terminal cross rabbits. J. Appl. Rabbit Res., 4: 66.

Wegmann T.G.and O. Smithies (1966). A simple hemagglutination system requiring and small amounts of red cells and antibodies. Transfusion, 6: $67-73$.

Yazdanparast, R. ; S. Bahramikia and A. Ardestani (2008). Nasturtium officinale reduces oxidative stress and enhances antioxidant capacity in hypercholesterolaemic rats. Chemico-Biological Interactions, 172: (15): 176-184

Zeweil, H. S. ; M. H. Ahmed ; M. M. Adawy and B. M. Zaki (2009). Effect of substitution rocket seed meal as a source of protein for soybean meal in diet of New Zealand White rabbits. $9^{\text {th }}$ World Rabbit Congress - June 10-13 - Verona - Italy. 859-862.

Zohara, Y. ; D. Schafferman and Z. Amarisrael (1998). Traditional used and biodiversity of rocket (Eruca sativa, Barassicaceae) in Israel. Economic Botany, 52: 394-400. 


\title{
تأثير استخدام زيت بذور الجرجير وزيت بذور البصل على الكفاعة الإنتاجية

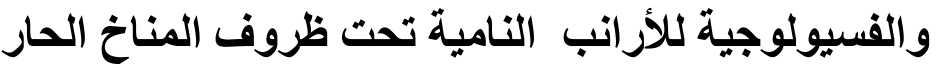

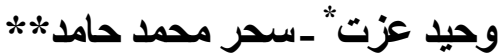

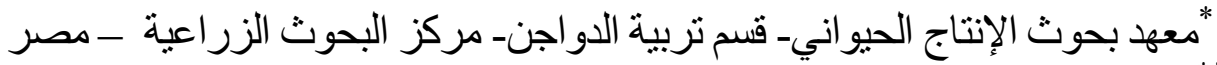

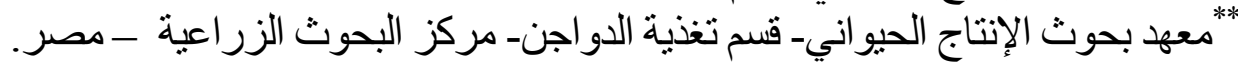

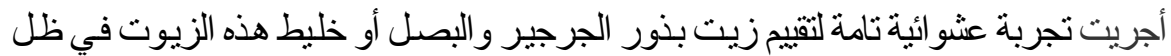

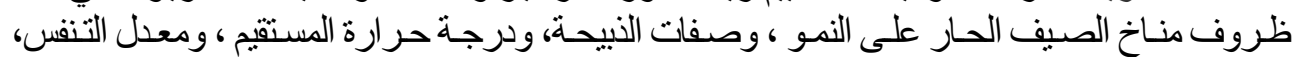

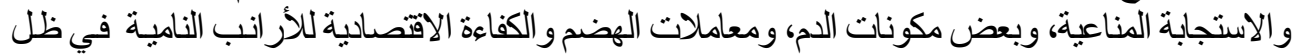

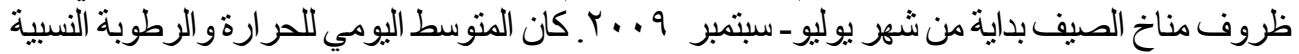

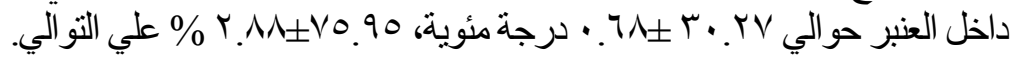

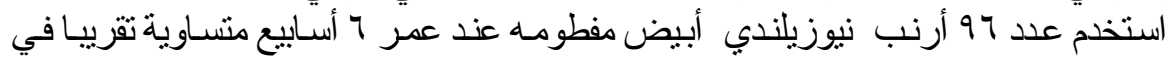

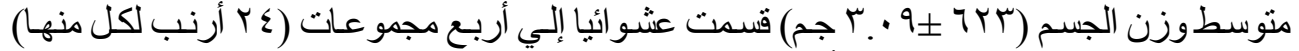

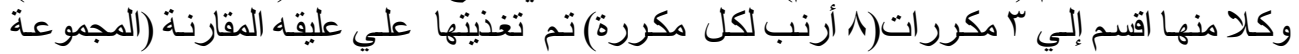

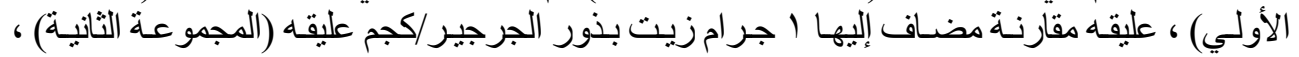

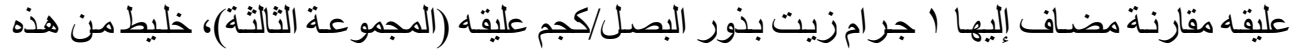

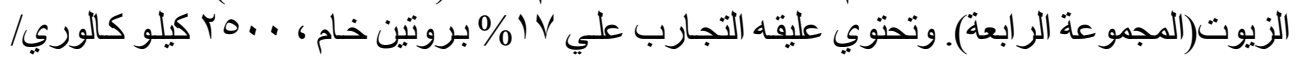

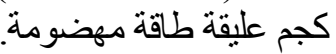

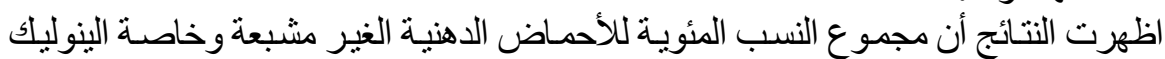

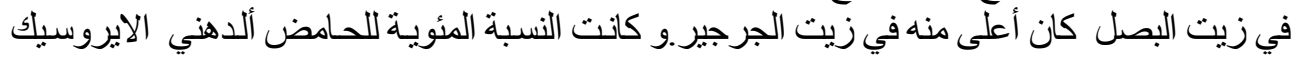

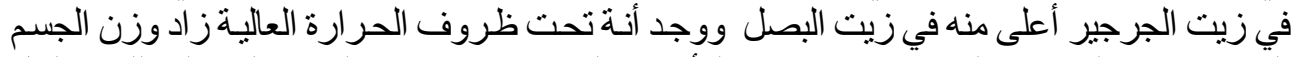

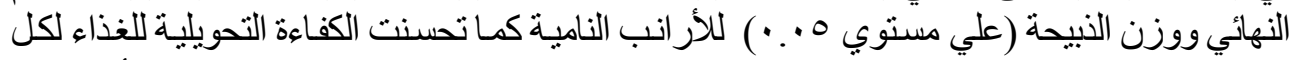

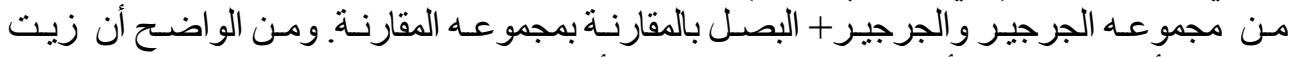

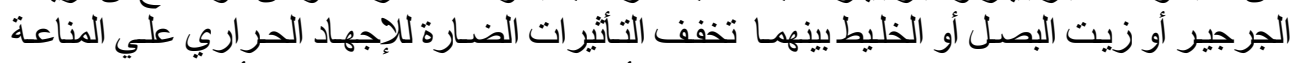

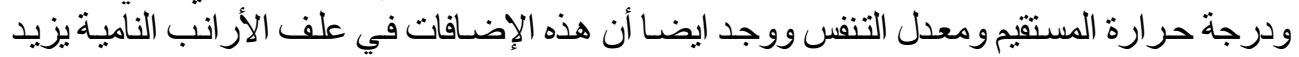

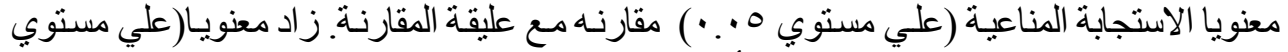

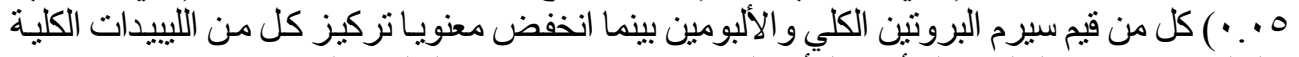

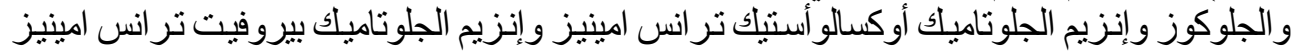

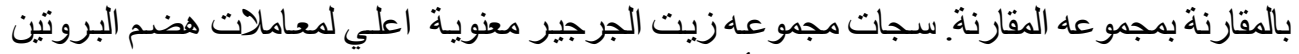

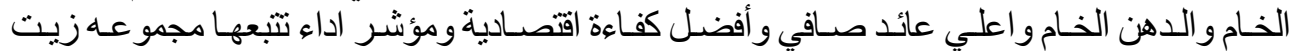

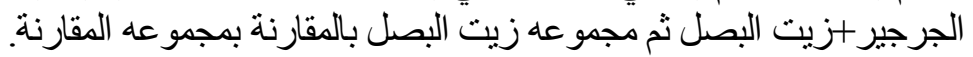

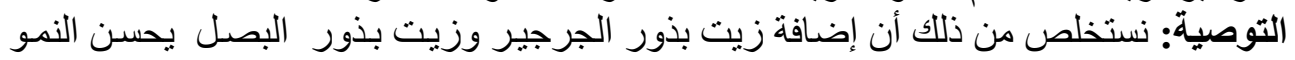

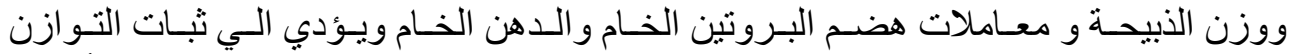

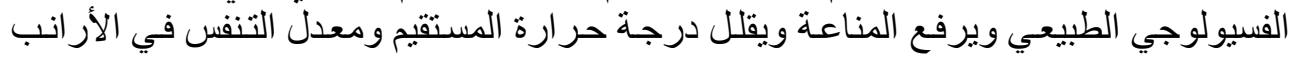

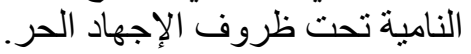

